\title{
Patterns of genetic variation among Canadian populations of the bird cherry-oat aphid, Rhopalosiphum padi L. (Homoptera: Aphididae)
}

\author{
JEAN-CHRISTOPHE SIMON* \& PAUL D. N. HEBERT \\ Department of Zoology, College of Biological Sciences, University of Guelph, Guelph, Ontario, Canada N1G 2W1
}

\begin{abstract}
Past allozyme studies have shown a very low level of genetic variation among aphid populations. Attempts have been made to link this lack of diversity to the biological characteristics of aphids. This study examines the effect of host-alternation on genetic diversity in Canadian populations of the aphid Rhopalosiphum padi. Allozyme analysis of 15 populations on the primary host and 14 on the secondary hosts revealed polymorphism at only three of 51 loci. Little geographical differentiation was observed among populations from a single host category. However, gene frequency differences were noted between populations on primary and those on secondary hosts at two of three polymorphic loci and the mean heterozygosity was substantially reduced on secondary hosts. This pattern might result from the admixture on secondary hosts of resident clones and relatively invariant migrants from southern areas. Alternatively, the decreased heterozygosity might result from either a selective disadvantage of heterozygotes on secondary hosts or their selective migration to other hosts.
\end{abstract}

Keywords: allozyme, cereal aphid, cyclical parthenogen, genetic diversity, host-alternation, Rhopalosiphum padi.

\section{Introduction}

Over the last two decades the genetic structure of aphid populations has received increasing attention as a result of the evolution of insecticide resistance, the appearance of biotypes overcoming plant resistance and the increasing spread of aphid-borne viruses. The most striking feature to emerge from these studies is the very low level of genetic variation (as measured by allozyme analysis) among aphid populations. While most other invertebrates show an average heterozygosity of 10 per cent (Nevo, 1978; Ayala, 1982; Graur, 1985), heterozygosities in aphids average only 1.5 per cent (Tomiuk \& Wöhrmann, 1980; Loxdale et al., 1985; Loxdale \& Brookes, 1990; Hebert et al., 1991). An effort has been made to link this unusually low level of variation to those biological characteristics of aphids which differentiate them from other invertebrate groups.

*Present address and correspondance: Laboratoire de Zoologie, Institut National de la Recherche Agronomique, B.P. 29, 35650 Le Rheu, France.
Most aphids are cyclical parthenogens. Although the sexual phase permits the generation of new gene combinations, it has been argued that selection during the parthenogenetic phase of the life cycle allows the amplification of high fitness genotypes resulting in the dominance of a few genotypes and impoverishment of variation (Wool et al., 1978; Simon et al., 1982). However, this explanation fails to account for the lack of similar low levels of genetic diversity in other cyclical parthenogens such as cladocerans or rotifers (Young, 1983; Hebert, 1987).

Other authors have linked the paucity of genetic variation to the complex relationships between aphids and their host plants. For example in host-alternating aphids (whose life cycle is achieved on a primary host, usually woody, and a secondary host, usually herbaceous), the switch from the primary to secondary hosts might be associated with population bottlenecks leading to the loss of genetic diversity (Loxdale \& Brookes, 1988). Similarly, aphids which exploit hosts of recent origin, such as cultivated plants, might have 
been exposed to founder effects during the transition from their natural hosts (Blackman, 1990; Hebert et al., 1991). Unfortunately, the effects of host shifts on the genetic structure of aphid populations are poorly documented.

Low levels of genetic diversity might also result from inbreeding since all aphids possess wingless morphs with very limited dispersal abilities. However, aphids can also produce winged forms with better dispersal capability. There is evidence that aphid species show varying flight capabilities (see Loxdale et al., 1993, for a recent review), but no good evidence that aphids, as a group, are more prone to inbreeding than other invertebrate groups.

More work is needed to determine how breeding system, host-alternation and dispersal abilities affect the genetic structure of the aphid populations. This study deals with Rhopalosiphum padi L., a cosmopolitan species whose life cycle is usually achieved on two different hosts. Sexual reproduction and cold-resistant egg laying occur in the autumn on a primary host, which is Prunus virginiana in North America. The secondary hosts consist of a variety of grass species on which several parthenogenetic generations are produced during the summer. Where winters are mild and the primary host is scarce, $R$. padi can reproduce parthenogenetically throughout the year on its secondary hosts (Dedryver \& Gellé, 1982; Simon et al., 1991). Apparently Palaearctic in origin (Blackman \& Eastop, 1984), R. padi was introduced into North America at least 150 years ago (Fitch, 1855). The species is thought to overwinter only as an egg in most of Canada excepting the Maritimes (Adams \& Drew, 1964) and British Columbia (Forbes, 1962) where the milder winters allow the survival of parthenogenetic lineages.

In this study we assess the extent of allozyme variation and the amount of genetic divergence among populations of $R$. padi from Ontario. We also examine the extent of seasonal variation in gene frequencies by comparing the genetic structure of these populations on their primary and secondary hosts.

\section{Materials and methods}

\section{Collections}

Individuals of Rhopalosiphum padi were collected in 1993 from 29 sites throughout Ontario (Fig. 1). Populations were collected on the primary host, Prunus virginiana, between May 17 and May 25 and on four cereal crops (barley, maize, oats and wheat) from July 15 to September 9. Sampling was designed to collect populations on closely adjacent primary and secondary hosts for each geographical area. An effort was made to collect at least 50 individuals per site, each from a different plant.

In collections from $P$. virginiana, we found Rhopalosiphum cerasifoliae Fitch on the same tree and even in the same pseudogall as $R$. padi. As these species are suspected to hybridize in North America ( $S$. E. Halbert, personal communication), we retained
Fig. 1 Location of the 29 Rhopalosiphum padi populations collected in Ontario. Circles indicate samples from the primary host, while squares indicate collections from secondary hosts. The letter before the population number refers to the secondary host plant from which the collection was made: $\mathrm{B}$, barley; C, corn (maize); O, oats; W, wheat.

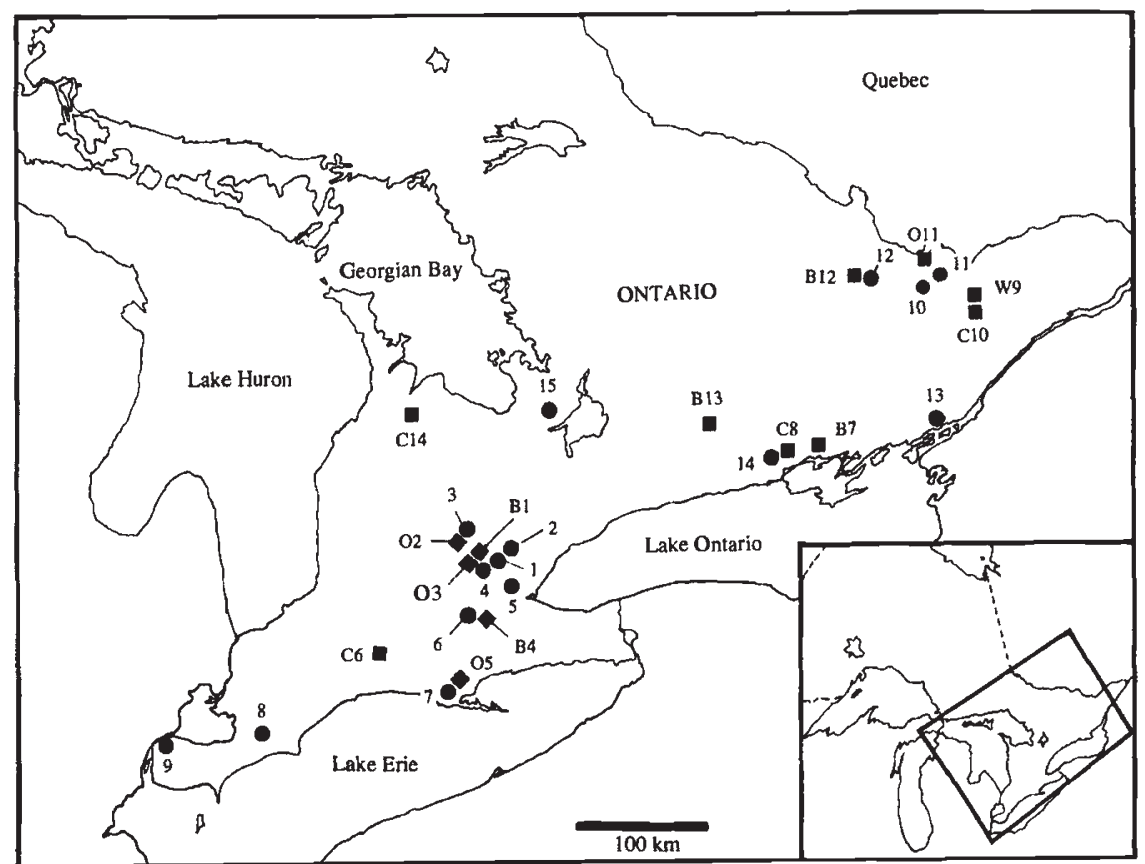


specimens of $R$. cerasifoliae from such admixed populations. All samples were stored at $-80^{\circ} \mathrm{C}$ until use.

\section{Allozyme analysis}

Allozyme analysis was carried out on single individuals and performed on cellulose acetate gels using standard methods (Hebert \& Beaton, 1989). Initially 24 individuals from 10 geographically separated populations were screened for polymorphic loci. A total of 51 loci was analysed (Table 1).

Loci were considered polymorphic if the mean frequency of the most common allele was $<0.95$. Based on this criterion, three loci were polymorphic in the initial survey: peptidase-1 (PEP), phosphoglucomutase $(P G M)$, and sorbitol dehydrogenase $(S D H)$. Two alleles $\left(R_{\mathrm{f}}=0.85,1.00\right)$ were detected at aminoaspartate transferase-2 $(A A T-2)$, but the mean frequency of the more common allele $\left(R_{\mathrm{f}}=1.00\right)$ was 0.99 , so this locus was excluded from subsequent analyses.

\section{Data analysis}

Data were analysed using the PC version of BIOSYs-1 (Swofford \& Selander, 1989). Genotypic frequencies were compared with Hardy-Weinberg (HW) expectations using Levene's exact method. Metric multidimensional scaling of Rogers's distance was used to assess genetic divergence among populations. F-statistics (Wright, 1965, 1978; Nei, 1977) were calculated to quantify gene frequency divergence.

\section{Results}

Polymorphism was detected at only 3 of the 51 loci $(5.9$ per cent) with three alleles present at PEP $\left(P E P^{0.70}\right.$, $P E P^{1.00}$ and $\left.P E P^{1.45}\right)$, two alleles at $P G M\left(P G M^{0.79}\right.$ and $\left.P G M^{1.00}\right)$ and two alleles at $S D H\left\langle S D H^{0.53}\right.$ and $\left.S D H^{1.00}\right)$. PEP showed a fuzzy heterozygous banding pattern making it difficult to infer the quaternary structure of this enzyme while $P G M$ had two-banded heterozygotes indicating a monomeric structure. $S D H$

Table 1 Names, E.C. numbers, and number of loci of enzymes analysed for variation in Canadian populations of Rhopalosiphum padi

\begin{tabular}{lcc}
\hline Enzyme name & E.C. number & Number of loci \\
\hline Aconitase & 4.2 .1 .3 & 2 \\
Adenylate kinase & 2.7 .4 .3 & 3 \\
Aldolase & 4.1 .2 .13 & 1 \\
Alkaline phosphatase & 3.1 .3 .1 & 1 \\
Aminoaspartate transferase & 2.6 .1 .1 & 2 \\
Amylase & 3.2 .1 .2 & 1 \\
Arginine phosphokinase & 2.7 .3 .3 & 4 \\
Diaphorase & 1.8 .1 .4 & 2 \\
Esterase & 3.1 .1 .1 & 4 \\
Fumarase & 4.2 .1 .2 & 1 \\
Glucokinase & 2.7 .1 .2 & 1 \\
Glucose phosphoisomerase & 5.3 .1 .19 & 1 \\
Glyceraldehyde-6-phosphate dehydrogenase & 1.2 .1 .12 & 1 \\
Glycerol-3-phosphate dehydrogenase & 1.1 .1 .8 & 1 \\
Glucose-6-phosphate dehydrogenase & 1.1 .1 .49 & 1 \\
Hexokinase & 2.7 .1 .1 & 3 \\
Hydroxybutyric dehydrogenase & 1.1 .1 .30 & 2 \\
Isocitrate dehydrogenase & 1.1 .1 .42 & 2 \\
Lactate dehydrogenase & 1.1 .1 .27 & 1 \\
Leucine aminopeptidase & 3.4 .11 .1 & 2 \\
Malate dehydrogenase & 1.1 .1 .37 & 2 \\
Malic enzyme & 1.1 .1 .40 & 1 \\
Mannose phosphate isomerase & 5.3 .1 .18 & 1 \\
Peptidases & $3.4 .13 .11 / 3.4 .11 .4$ & 4 \\
Phosphoglucomutase & 5.4 .2 .2 & 1 \\
6-phosphogluconate dehydrogenase & 1.1 .1 .43 & 1 \\
Sorbitol dehydrogenase & 1.1 .1 .44 & 1 \\
Triosephosphate isomerase & 5.3 .1 .1 & 2 \\
Xanthine dehydrogenase & 1.1 .1 .204 & 2 \\
\hline
\end{tabular}


showed five-banded heterozygotes suggesting a tetrameric structure, as opposed to the trimeric structure previously described for $R$. padi (Loxdale \& Brookes, 1988).

One allele was common at each locus, while the other alleles had mean frequencies less than 0.20 (Table 2). Hardy-Weinberg (HW) deviations were only noted at PEP and included two populations from the primary host and three from the secondary hosts. In all cases the deviations were the result of heterozygote deficiency. Gene frequencies were similar, even among distant populations, for collections from either the primary or secondary hosts. However, significant differences in gene frequency at two of the three polymorphic loci did exist between populations from primary and secondary hosts (Table 3). Multidimensional scaling of the genetic distances among all 29 populations revealed two groups linked to host-plant category (Fig. 2). The populations from primary hosts were ordinarily differentiated from those on secondary hosts by their lower frequency of the more common allele at all three loci.

Correlated with the gene frequency shift from primary to secondary hosts, the mean heterozygosity $(\bar{H})$ over the three polymorphic loci also showed a significant difference $(P<0.001)$ between populations

Table 2 Comparison of allele frequencies at three allozyme loci in populations of Rhopalosiphum padi on primary and secondary hosts in Ontario

\begin{tabular}{|c|c|c|c|c|c|c|c|c|}
\hline \multirow[b]{2}{*}{ Population } & \multirow[b]{2}{*}{$N$} & \multicolumn{2}{|c|}{$S D H$} & \multicolumn{2}{|c|}{$P G M$} & \multicolumn{3}{|c|}{$P E P$} \\
\hline & & 0.53 & 1.00 & 0.79 & 1.00 & 0.70 & 1.00 & 1.45 \\
\hline \multicolumn{9}{|l|}{ Primary host } \\
\hline 1 & 102 & 0.044 & 0.956 & 0.069 & 0.931 & 0.020 & 0.784 & 0.196 \\
\hline 2 & 96 & 0.005 & 0.995 & 0.063 & 0.938 & 0.026 & 0.802 & 0.172 \\
\hline 3 & 144 & 0.059 & 0.941 & 0.104 & 0.896 & 0.028 & 0.823 & 0.149 \\
\hline 4 & 98 & 0.056 & 0.944 & 0.026 & 0.974 & 0.051 & 0.781 & 0.168 \\
\hline 5 & 61 & 0.074 & 0.926 & 0.057 & 0.943 & 0.008 & 0.836 & 0.156 \\
\hline 6 & 54 & 0.019 & 0.981 & 0.019 & 0.981 & 0.056 & 0.769 & 0.176 \\
\hline 7 & 74 & 0.020 & 0.980 & 0.068 & 0.932 & 0.014 & 0.865 & 0.122 \\
\hline 8 & 50 & 0.020 & 0.980 & 0.040 & 0.960 & 0.040 & 0.800 & 0.160 \\
\hline 9 & 94 & 0.000 & 1.000 & 0.005 & 0.995 & 0.000 & 0.819 & 0.181 \\
\hline 10 & 98 & 0.015 & 0.985 & 0.051 & 0.949 & 0.082 & 0.791 & 0.128 \\
\hline 11 & 59 & 0.008 & 0.992 & 0.017 & 0.983 & 0.017 & 0.949 & 0.034 \\
\hline 12 & 51 & 0.000 & 1.000 & 0.074 & 0.926 & 0.032 & 0.947 & 0.021 \\
\hline 13 & 96 & 0.000 & 1.000 & 0.141 & 0.859 & 0.005 & 0.797 & 0.198 \\
\hline 14 & 98 & 0.026 & 0.974 & 0.092 & 0.908 & 0.051 & 0.806 & 0.143 \\
\hline 15 & 64 & 0.055 & 0.945 & 0.133 & 0.867 & 0.000 & 0.859 & 0.141 \\
\hline \multicolumn{9}{|c|}{$N=1239$} \\
\hline
\end{tabular}

Secondary hosts

\begin{tabular}{|c|c|c|c|c|c|c|c|c|}
\hline B1 & 96 & 0.005 & 0.995 & 0.052 & 0.948 & 0.010 & 0.932 & 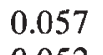 \\
\hline $\mathrm{O} 2$ & 96 & 0.005 & 0.995 & 0.031 & 0.969 & 0.005 & 0.943 & 0.0 \\
\hline O3 & 72 & 0.000 & 1.000 & 0.042 & 0.958 & 0.000 & 0.965 & 0.03 \\
\hline B4 & 50 & 0.000 & 1.000 & 0.010 & 0.990 & 0.000 & 0.850 & \\
\hline O5 & 81 & 0.000 & 1.000 & 0.000 & 1.000 & 0.012 & 0.981 & \\
\hline C6 & 103 & 0.000 & 1.000 & 0.073 & 0.927 & 0.010 & 0.937 & \\
\hline B7 & 50 & 0.012 & 0.988 & 0.024 & 0.976 & 0.036 & 0.881 & \\
\hline $\begin{array}{c}\text { C8 } \\
\text { W9 }\end{array}$ & 96 & 0.036 & 0.964 & 0.115 & 0.885 & 0.000 & 0.865 & \\
\hline W9 & 96 & 0.000 & 1.000 & 0.016 & 0.984 & 0.016 & 0.938 & 0. \\
\hline $\mathrm{C} 10$ & 108 & 0.000 & 1.000 & 0.088 & 0.912 & 0.000 & 0.954 & \\
\hline O11 & 81 & 0.012 & 0.988 & 0.049 & 0.951 & 0.062 & 0.883 & 0 \\
\hline $\begin{array}{l}\text { B12 } \\
\text { B1 }\end{array}$ & 62 & 0.008 & 0.992 & 0.008 & 0.992 & 0.000 & 0.984 & 0. \\
\hline $\begin{array}{l}\text { B13 } \\
\text { C14 }\end{array}$ & 53 & 0.000 & 1.000 & 0.028 & 0.972 & 0.000 & 0.962 & 0. \\
\hline C14 & 60 & 0.017 & 0.983 & 0.033 & 0.967 & 0.025 & 0.967 & \\
\hline
\end{tabular}

Alleles are coded by their relative mobility values.

Secondary hosts: B, barley; C, corn (maize); O, oats; W, wheat. 
Table 3 Mean allele frequencies and standard errors (in parentheses) at the three polymorphic loci in Rhopalosiphum padi populations on primary and secondary hosts

\begin{tabular}{lccc}
\hline & & \multicolumn{2}{c}{ Allele frequency } \\
\cline { 3 - 4 } Locus & Allele & Primary hosts & Secondary hosts \\
\hline \multirow{2}{*}{$S D H$} & 0.53 & $0.027(0.0007) \mathrm{a}$ & $0.007(0.0003) \mathrm{b}$ \\
& 1.00 & $0.973(0.0007) \mathrm{a}$ & $0.993(0.0003) \mathrm{b}$ \\
PGM & 0.79 & $0.064(0.0012) \mathrm{a}$ & $0.041(0.0010) \mathrm{a}$ \\
& 1.00 & $0.936(0.0012) \mathrm{a}$ & $0.959(0.0010) \mathrm{a}$ \\
PEP & 0.70 & $0.029(0.0007) \mathrm{a}$ & $0.013(0.0005) \mathrm{b}$ \\
& 1.00 & $0.828(0.0016) \mathrm{a}$ & $0.931(0.0013) \mathrm{b}$ \\
& 1.45 & $0.143(0.0015) \mathrm{a}$ & $0.056(0.0017) \mathrm{b}$ \\
\end{tabular}

Means in a row followed by the same letter are not significantly different $(P>0.01)$.

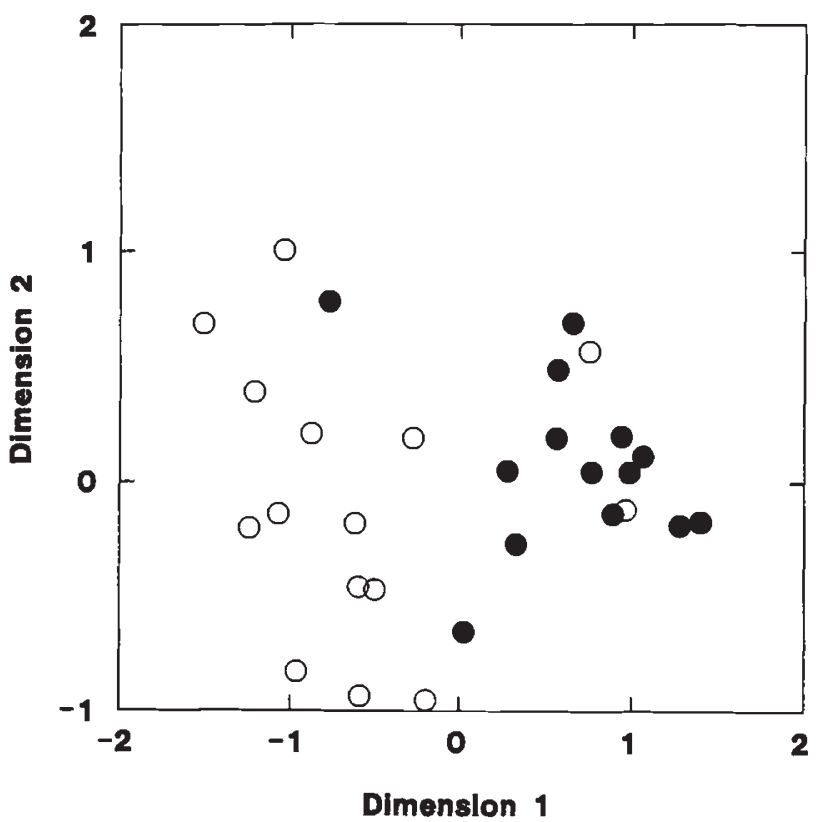

Fig. 2 Two-dimensional scaling of Rogers's genetic distances among Rhopalosiphum padi populations collected on their primary host (clear circles) or their secondary hosts (solid circles). on $P$. virginiana $(\bar{H}=0.149)$ and those on cereals $(\bar{H}=0.074)$. Furthermore, populations on secondary hosts showed a reduced polymorphism compared with those on $P$. virginiana. For example, only three of 15 populations from the primary host were invariant at $S D H$, whereas seven of 14 populations from the secondary hosts were fixed at this locus.

$F$-statistics showed very low $F_{\text {Is }}$ and $F_{\text {sT }}$ values at all loci (Table 4) and no significant differences in the degree of population subdivision between populations on the primary and secondary hosts.

Rhopalosiphum cerasifoliae and $R$. padi were allozymically distinctive with allele substitutions at eight loci including aminoaspartate transferase-2, glucose-6phosphate dehydrogenase, glyceraldehyde-6-phosphate dehydrogenase, glycerol-3-phosphate dehydrogenase, isocitric dehydrogenase-2, peptidase-1, phosphoglucomutase and sorbitol dehydrogenase. Based on these allelic substitutions, hybrids would have been easily diagnosed, but none was detected.

\section{Discussion}

Populations of $R$. padi from Ontario were polymorphic at 5.9 per cent of their loci, a value slightly less than the 9 per cent average for aphids (Tomiuk \& Wörhmann, 1980). Allozyme studies on British populations of $R$. padi showed that two of 14 loci were variable including $A A T-2$ and $S D H$ (Loxdale \& Brookes, 1988). These same loci were also variable in Canadian populations (although AAT-2 was nearly fixed for the dominant European allele) as well as two other loci ( $P G M$ and $P E P)$. The mean heterozygosity of individuals of $R$. padi ( $\bar{H}=0.6$ per cent) from Ontario also appears slightly lower than the 1.5 per cent average noted for other aphids (Tomiuk \& Wörhmann 1980, 1983; Loxdale \& Brookes, 1990; Hebert et al., 1991).

The analysis of genotypic frequency distributions revealed little regional differentiation among $R$. padi populations in Ontario, a result congruent with those obtained over a similar geographical scale in Britain (Loxdale \& Brookes, 1988). The authors of this earlier study suggested that the migratory behaviour of this

Table $4 F$-statistics values for Rhopalosiphum padi populations on their primary and secondary hosts

\begin{tabular}{|c|c|c|c|c|c|c|c|c|c|}
\hline \multirow[b]{2}{*}{ Locus } & \multicolumn{3}{|c|}{ Primary host } & \multicolumn{3}{|c|}{ Secondary hosts } & \multicolumn{3}{|c|}{ Overall } \\
\hline & $F_{\text {IS }}$ & $F_{\mathrm{ST}}$ & $F_{\mathrm{IT}}$ & $F_{\text {IS }}$ & $F_{\mathrm{ST}}$ & $F_{\mathrm{IT}}$ & $F_{\text {IS }}$ & $F_{\mathrm{ST}}$ & $F_{\mathrm{IT}}$ \\
\hline$S D H$ & -0.050 & 0.022 & -0.027 & -0.022 & 0.014 & -0.007 & -0.045 & 0.026 & -0.017 \\
\hline$P G M$ & -0.053 & 0.026 & -0.026 & -0.069 & 0.025 & -0.042 & -0.059 & 0.028 & -0.029 \\
\hline$P E P$ & 0.055 & 0.020 & 0.074 & -0.009 & 0.029 & 0.020 & 0.036 & 0.043 & 0.078 \\
\hline Mean & 0.015 & 0.022 & 0.037 & -0.031 & 0.027 & -0.004 & 0.001 & 0.037 & 0.039 \\
\hline
\end{tabular}


species was responsible for the lack of geographical patterning in gene frequencies. The very low $F_{S T}$ values noted in our study provide further evidence for the high vagility of $R$. padi, as it is generally accepted that dispersal abilities are inversely related to $F_{\text {ST }}$ values (Daly, 1989; Loxdale, 1990; Hebert et al., 1991). However, any attempt to infer migration rates from gene frequency divergence rests on the assumption that gene frequency distributions are at equilibrium, a presumption which is often unjustified (Boileau et al., 1992).

Our results showed that genotypic frequencies in populations of $R$. padi approximated HW expectations on both the primary host, just after sexual reproduction, and on the secondary hosts, after several generations of parthenogenesis. These observations are in agreement with many other aphid studies (Wörhmann \& Tomiuk, 1989; Loxdale \& Brookes, 1990) and support the general view that the genotypic characteristics of these cyclical parthenogens approximate those of fully sexual species (Hebert, 1987). However, our study did reveal the occurrence of some heterozygote deficits $-\mathrm{a}$ result also obtained in several prior studies. In their work on Canadian populations of the rose aphid, Macrosiphum rosae, Rhomberg et al., (1985) found large heterozygote deficits and suggested that they were a direct consequence of clonal proliferation and the diffusion of a small number of genotypes. Similar HW deviations in Sitobion avenae were attributed to its complete loss of sexual reproduction (Loxdale et al., 1985) whereas those noted for the sumac aphid Melaphis rhois were linked to inbreeding (Hebert et al., 1991). In this study HW deviations were found only at the PEP locus in two populations from the primary host and three from secondary hosts. As populations on the primary host result directly from sexual reproduction, HW departures cannot be a consequence of asexual amplification, and they might simply be a sampling artefact.

The most striking finding of this study concerns the pattern of change in gene frequencies between populations on the primary host and those on secondary hosts. This included a shift in allele frequencies at two of the three polymorphic loci and the impoverishment of the mean heterozygosity of aphids on secondary hosts. This reduction in heterozygosity is such that aphids on the secondary host were only 40 per cent as heterozygous as those on primary hosts.

The effect of host-alternation on the genetic structure of aphid populations has only been assessed in two prior studies. No significant differences in gene frequencies were found between populations of Phorodon humuli on its primary and secondary hosts, but sample sizes on the primary host were very small (Eggers-Schumacher \& Sander, 1988). Loxdale \&
Brookes (1990) found that populations of Sitobion fragariae had lower heterozygosity on primary than secondary hosts. They attributed this difference to either a reduction of gene flow on the secondary host or to occurrence of both holocyclic and anholocyclic strains on the secondary host, but only holocyclics on the primary host.

Ontario populations of $R$. padi showed a different pattern of variation, with lower heterozygosity on secondary than primary hosts. There are two potential explanations for this decrease in heterozygosity. Firstly, since populations on secondary hosts may include both resident and migratory clones, the decrease in heterozygosity could result from the invasion of relatively invariant migrants. To explain the 60 per cent reduction in heterozygosity, this percentage of $R$. padi on secondary hosts would need to derive from completely invariant migrant clones. If migrants were not completely homozygous, but only less variable than residents, then the proportion of migrant clones would need to be even higher.

Alternatively, the decrease in heterozygosity might result from either the selective disadvantage of heterozygotes on secondary hosts or from the selective migration of heterozygous lineages to other hosts. Prior workers have invoked clonal selection to explain genotypic frequency shifts on a single host. For example, Rhomberg et al. (1985) attributed a reduction in heterozygotes at EST-4 in $M$. rosae to selection. Instead of selection on single hosts, it is also possible that $R$. padi includes a number of biotypes with very limited genetic divergence. Those biotypes might share the use of $P$. virginiana as a primary host, but move, in the summer, to different secondary hosts. Our collections on secondary hosts were limited to four cereal crops, but $R$. padi colonizes a broad range of Gramineae as well as Juncaceae and Cyperaceae (Rautapää, 1970; Markkula \& Roukka, 1972). Under this model, certain biotypes with relatively high frequencies of otherwise rare alleles at the $S D H$ and $P E P$ loci would need to move to these alternative secondary hosts to account for the low heterozygosity on those secondary hosts which were investigated.

More work is required to resolve the causation of the seasonal gene frequency shifts in $R$. padi. Firstly, it should be established that annual gene frequency shifts in this species are recurrent. Genetic analysis of $R$. padi from the southeastern United States is critical to ascertain the likelihood that heterozygosity shifts arise from the infusion of migrant clones with low levels of variation. Surveys of gene frequency in $R$. padi from a broader range of its secondary hosts in Ontario could establish the role of biotypes in accounting for the seasonal gene frequency shift. If these studies fail to account for the heterozygosity decline, then the loss of 
diversity is likely to result from selection on the secondary hosts. This latter mechanism is important as it would tie the genetic impoverishment in $R$. padi to the phenomenon of host-alternation.

\section{Acknowledgments}

This research was supported by grants from the North Atlantic Treaty Organization and the Institut National de la Recherche Agronomique to J.-C. S. and by a research grant from the Natural Sciences and Engineering Research Council of Canada to PDNH. We thank Derek Taylor for an earlier draft of the manuscript; Robert Foottit and Eric Maw for helping with the aphid collections, and Paul Forde for drawing Fig. 1.

\section{References}

ADAMS, J. B. AND DREW, M. E. 1964. Grain aphids in New Brunswick. I. Field development on oats. Can. J. Zool., 42, 735-740.

AYALA, F. J. 1982. Genetic variation in natural populations: problems of electrophoretically cryptic alleles. Proc. Natl. Acad. Sci. U.S.A., 79, 550-554.

BLACKMAN, R. L. 1990. Specificity in aphid-plant interactions with particular attention to the role of the alate colonizer. In: Campbell, R. K. and Eikenbary, R. D. (eds) Aphid-Plant Genotype Interactions, pp. 251-274. Elsevier, Amsterdam.

BLACKMAN, R. L. AND EASTOP, v. F. 1984. Aphids on the World's Crops. An Identification Guide. John Wiley and Sons, Chichester.

BOILEAU, M. G., HEBERT, P. D. N. AND SCHWARTZ, s. s. 1992. Nonequilibrium gene frequency divergence: persistent founder effects in natural populations. J. Evol. Biol., 5, 25-39.

DALY, J. C. 1989. The use of electrophoretic data in a study of gene flow in the pest species Heliothis armigera (Hubner) and $H$. punctigera (Wallengren) (Lepidoptera: Noctuidae). In: Loxdale, H. D. and Den Hollander, J. (eds) Electrophoretic Studies on Agricultural Pests, pp. 115-141. Clarendon Press, Oxford.

DEDRYVER, C. A. AND GELlE, A. 1982. Biologie des pucerons des céréales dans l'ouest de la France. IV. -Etude de l'hivernation des populations anholocycliques de Rhopalosiphum padi L., Metopolophium dirhodum Wlk. et Sitobion avenae $\mathrm{F}$. sur repousses de céréales dans trois stations de Bretagne et du Bassin parisien. Acta Oecologica Oecol. Applic., 3, 321-342.

EGGERS-SCHUMACHER, H. A. AND SANDER, E. 1988. Spatial and seasonal genetic (allozyme) variation within field populations of Phorodon humuli Schrank (Homoptera: Aphididae). The Entomologist, 107, 110-121.

FITCH, A. 1855. The first report on the noxious, beneficial and other insects of the state of New York. Trans. N. Y. Agric. Soc., 14, 705-880.

FORBES, A. R. 1962. Aphid populations and their damage to oats in British Columbia. Can. J. Plant Sci., 42, 660-666.
GRAUR, D. 1985. Gene diversity in Hymenoptera. Evolution, 39, 190-199.

HEBERT, P. D. N. 1987. Genotypic characteristics of cyclic parthenogens and their obligately asexual derivatives. In: Stearns, S. J. (ed) The Evolution of Sex and its Consequences, pp. 175-195. Birkhaüser Verlag, Basel.

HEBERT, P. D. N. AND BEATON, M. J. 1989. Methodologies for Allozyme Analysis Using Cellulose Acetate Electrophoresis. Helena Laboratories, Beaumont, TX.

HEBERT, P. D. N., FINSTON, T. L. AND FOoTTIT, R. 1991. Patterns of genetic diversity in the sumac aphid, Melaphis rhois. Genome, 34, 757-762.

LOXDALE, H. D. 1990. Estimating levels of gene flow between natural populations of cereal aphids (Homoptera: Aphididae). Bull. ent. Res., 80, 331-338.

LOXDALE, H. D. AND BROOKES, C. P. 1988. Electrophoretic study of enzymes from cereal aphid populations. V. Spatial and temporal similarity between holocyclic populations of the bird cherry oat aphid Rhopalosiphum padi (L.) (Hemiptera: Aphididae) in Britain. Bull. ent. Res., 78, 241-249.

LOXDALE, H. D. AND BROOKES, C. P. 1990.Temporal genetic stability within and restricted migration (gene flow) between local populations of the blackberry-grain aphid Sitobion fragariae in south-east England. J. Anim. Ecol., 59, 495-512.

LOXDALE, H. D., TARR, I. J., WEBER, C. P., BROOKES, C. P., DIGBY, P. G. N. AND CASTAÑERA, P. 1985. Electrophoretic study of enzymes from cereal aphid populations. III. Spatial and temporal genetic variation of populations of Sitobion avenae (F.) (Hemiptera: Aphididae). Bull. ent. Res., 75, 121-141.

LOXDALE, H. D., HARDIE, J., HALBERT, S., FOOTTIT, R., KIDD, A. C. AND CARTER, C. I. 1993. The relative importance of short- and long-range movement in flying aphids. Biol. Rev., 68, 291-311.

MARKKULA, M. AND ROUKKA, K. 1972. Resistance of cereals to the aphids Rhopalosiphum padi (L.) and Macrosiphum avenae (F.) and fecundity of these aphids on Gramineae, Cyperaceae and Juncaceae. Ann. Agric. Fenn., 11, 417-423.

NEI, M. 1977. F-statistics and analysis of gene diversity in subdivided populations. Ann. Hum. Genet., 41, 225-233.

NEVO, E. 1978. Genetic variation in natural populations: patterns and theory. Theor. Pop. Biol., 13, 121-177.

RAUTAPÄÄ, J. 1970. Preference of cereal aphids for various cereal varieties and species of Gramineae, Juncaceae and Cyperaceae. Ann. Agric. Fenn., 9, 267-277.

RHOMBERG, L. R., JOSEPH, S. AND SINGH, R. S. 1985. Seasonal variation and clonal selection in cyclically parthenogenetic rose aphids (Macrosiphum rosae). Can. J. Genet. Cytol., 27, 224-232.

SIMON, J. P., PARENT, M. A. AND AUClaiR, J. L. 1982. Isozyme analysis of biotypes and field populations of the pea aphid Acyrthosiphon pisum. Entomologia exp. appl., 32, 186-192.

SIMON, J.-C., BLACKMAN, R. L. AND LE GALLIC, J. F. 1991. Local variability in the life-cycle of the bird cherry-oat aphid, Rhopalosiphum padi (Homoptera: Aphididae) in western France. Bull. ent. Res., 81, 315-322.

SWOFFORD, D. L. AND SELANDER, R. B. 1989. BIosys-1. A Computer Program for the Analysis of Allelic Variation in Population 
Genetics and Biochemical Systematics. Illinois Natural History Survey, Urbana, II.

TOMIUK, J. AND WORHMANN, K. 1980. Enzyme variability in populations of aphids. Theor. Appl. Genet., 57, 125-127. TOMIUK, J. AND WÖRHMANN, K. 1983. Enzyme polymorphism and taxonomy of aphid species. Z. Zool. Syst. Evolutionsforsch., 21, 266-274.

WORHMANN, K. AND TOMIUK, J. 1989. Study of the variation of aphid populations using enzymes and other traits. In: Loxdale, H. D. and Den Hollander, J. (eds) Electrophoretic Studies on Agricultural Pests, pp. 203-229. Clarendon Press, Oxford.

WOOL, D., BUNTING, S. AND VAN EMDEN, H. F. 1978. Electrophore- tic study of genetic variation in British Myzus persicae (Sulz.) (Hemiptera: Aphididae). Biochem. Genet., 16, 987-1006.

WRIGHT, s. 1965. The interpretation of population structure by F-statistics with special regard to systems of mating. Evolution, 19, 395-420.

WRIGHT, s. 1978. Evolution and the Genetics of Populations, vol. 4, Variability Within and Among Natural Populations. University of Chicago Press, Chicago.

YOUNG, J. P. W. 1983. The population structure of cyclic parthenogens. In: Oxford, G. S. and Rollinson, B. (eds) Protein Polymorphism: Adaptative and Taxonomic Significance, pp. 362-378. Academic Press, London. 